female figurines pointing to affinities with the Anatolian mother-goddess, a variety of beads and amulets, and a store of wheat, the earliest probably in Mesopotamia. Excavations are being carried through the lower levels in the hope of reaching virgin soil.

\section{Road Research Station, Harmondsworth}

IN accordance with a recommendation of the Select Committee on Estimates of the House of Commons in its Second Report for 1932, arrangements have been made for the Road Research Station at Harmondsworth to be transferred from the Ministry of Transport to the Department of Scientific and Industrial Research as from April 1 last. The Committee of the Privy Council for Scientific and Industrial Research has decided to appoint a Road Research Board to advise generally on the conduct of road research undertaken by the Department, and with the concurrence of the Ministry of Transport, has appointed Major F. C. Cook, deputy chief engineer, Roads Department, Ministry of Transport, to be the first chairman of the Board. The following gentlemen have accepted invitations to serve on the Board :--Prof. R. G. H. Clements, Mr. T. Pierson Frank, Mr. W. J. Hadfield, Mr. W. P. Robinson, Prof. C. G. Cullis, Mr. E. V. Evans, Prof. E. H. Lamb, Prof. C. H. Lees, Lieut.-Col. Mervyn O'Gorman, and Dr. T. Franklin Sibly. The immediate direction and control of road research undertaken by the Department of Scientific and Industrial Research will be in the hands of Dr. R. E. Stradling, director of building research under the Department. Road tests throughout Great Britain under normal traffic conditions will continue, as heretofore, to be carried out by the Ministry of Transport in conjunction with the responsible highway authorities. In connexion with these tests, as well as the research work at the laboratory, and the issue of reports thereon, arrangements have been made for the closest collaboration between the Ministry of Transport and the Department of Scientific and Industrial Research.

\section{Science Teaching}

IN connexion with the notice of Badcock and Holmyard's "Electricity and Magnetism for Beginners" in Nature of March 11, Dr. Dorothy Turner protests against the suggestion that a good qualitative treatment may involve the danger of dulling the pupils' subsequent interest in the subject when the time comes for more complete quantitative treatment, on the ground that for ninety-five per cent of those attending State-aided secondary schools such a time never comes. We referred Dr. Turner's letter to the reviewer who, however, still maintains that the essential danger to which teachers of science will have to give serious consideration is that, in the otherwise laudable desire to extend the ground covered, anything worthy to be called a training in scienoe may be superseded by just talking about science, with the consequence that the subject may become little more than a branch of English, providing good topies for general knowledge essays.

\section{Rockefëller Gift to the Royal Institution}

IT was announced by the Managers of the Royal Institution at the general monthly meeting of the members, held on May 8, that the capital payment of $£ 20,000$ promised by the Rockefeller Foundation nearly three years ago, on condition of obtaining $£ 50,000$ from other sources, had now been received. The gift was promised for the endowment of research in the Davy Faraday Research Laboratory of the Royal Institution, and the fulfilment of the Rockefeller promise implies that in the past three years the Managers have been successful in securing research endowment for the Laboratory to a total capital value of upwards of $£ 70,000$.

\section{Spurious University Degrees}

A BILL to prohibit the unauthorised use and issue of university degrees, a subject which has been taken up by the Association of Scientific Workers, was introduced into the House of Lords by Lord Jessel on May 3 and read a first time. The main part of the Bill, which, if passed, will be known as the University Spurious Degrees (Prohibition of Use and Issue) Act, proposes to make it a penal offence for any person to use letters after his name denoting a university degree unless he actually holds such a degree; and also it prohibits the conferment of degrees by any person or organisation other than a recognised university. The term "recognised university" is defined at length; briefly, it may be described as a university or similar institution gxanting academic degrees as a result of a prescribed course of at least three years' training or definitely recognised as a university by the government of the country where it is situated. The "Lambeth degrees" conferred by the Archbishop of Canterbury are definitely exempted from the provisions of the Act.

\section{Californian Earthquake of March ro}

Tris earthquake has been studied by Messrs. H. O. Wood and C. F. Richter, seismologists of the Pasadena Seismological Laboratory, and a summary of their results appears in the Mail Report of Science Service, Washington, D.C. for April 19. The intensity of the shock was far less than that of the Nevada earthquake of November 20-21, and may have been less than that of the Santa Barbara earthquake of June 29, 1925. The greater loss of life (about 120 persons) and property caused by the recent shock is attributed to the strongly shaken area being more thickly settled. In some places, considerable destruction occurred and this was probably due to the water-soaked alluvial nature of the ground; but, in all, serious damage was confined to bad or improperly designed construction. The study of the records of seven seismographs in California under the charge of the Pasadena Laboratory shows that the origin of the earthquake was probably in one of a system of faults that runs parallel to the coast in the district between Huntington Beach and Newport Beach. The depth of the focus seems to have been less than usual and was probably about six miles. Nearly continuous 
movements were recorded for many hours afterwards, but none of the after-shocks was comparable with the main earthquake.

\section{Announcements}

The first conversazione this year of the Royal Society will be held in the rooms of the Society at Burlington House, London, W.1, on May 17, at 8.30 p.m.

Prof. Henry E. Armstrong will deliver the sixth Hugo Müller lecture before the Chemical Society, in the meeting hall of the Institution of Mechanical Engineers, on May 25, at 5.30. The title of the lecture will be "Chemistry at the Cross Roads".

Mr. H. Bradley will deliver the nineteenth "Physics in Industry" lecture before the Institute of Physics at the Royal Institution, 21 Albemarle Street, W.1, on May 23 at 5.15 p.m. The title of the lecture will be "Physics in the Boot and Shoe Industry".

ThE Halley lecture for 1933 of the University of Oxford will be delivered in the lecture theatre at the University Museum on June 1, at 5 p.m., by Prof. Henry Norris Russell, professor of astronomy and director of the Observatory, Princeton University. The subject will be "The Composition of the Stars".

Aт the ordinary meeting of the Royal Society of Edinburgh, held on May 1, the James Scott Prize for 1933 for an essay or lecture on the fundamental concepts of natural philosophy, was presented to Prof. Arnold Sommerfeld, professor of natural philosophy in the University of Munich. Prof. Sommerfeld, whose lecture was entitled "Ways to the Knowledge of Nature", dealt with a recent book of similar title by Prof. Max Planck, and gave his own views on such questions as the mathematical character of the laws of Nature, causality, duality in physics and in human life.

Ar the anniversary meeting of the Royal Society of South Africa, held on March 15, the following officers for the year 1933 were elected :-President : Dr. A. W. Rogers ; Hon. Treasurer: Prof. L. Crawford; Hon. General Secretary: Dr. B. F. J. Schonland.

Mr. H. T. Pagden, assistant entomologist in the Agricultural Department, Straits Settlements, has been appointed by the Secretary of State for the Colonies to be entomologist in the British Solomon Islands Protectorate.

IN our issue of April 29, p. 612, reference was made to resignations of Jewish professors from university chairs in Germany. During the past few days, the following three distinguished chemists have resigned their posts : Prof. F. Haber, director of the Kaiser Wilhelm Institut für physikalische Chemie und Elektrochemie, Berlin-Dahlem, who was awarded the Rumford medal for 1932 of the Royal Society for his work on.physical chemistry, notably in the application of thermodynamics to chemical reactions ; Prof. H. Freundlich, author of works on colloid chemistry, and Prof. M. Polanyi, distinguished for his work on physical chemistry, both of whom were also at the Kaiser Wilhelm Institut.

The Society for Cultural Relations between the Peoples of the British Commonwealth and the U.S.S.R. is organising tours of medical men and scientific workers to the U.S.S.R., and the first party will leave London for Leningrad on July 1. The return journey will cost $£ 22-£ 36$ inclusive, according to the type of accommodation selected. The party will spend a total of sixteen days in Russia; three days in Leningrad, five days in Moscow, then either (a) Gorky, down the Volga to Stalingrad-Leningrad; (b) Rostov/Don, Kharkov-Leningrad; or (c) Kharkov, Kiev-Leningrad. The latest date for receiving applications for the first party leaving London is June 15. Inquiries should be addressed to the Secretary of the S.C.R., 1 Montague Street, London, W.C.1.

ON May 23, the second part of a two volume work entitled "An Introduction to the Sociology of Islam", by Mr. Rueben Levy, lecturer in Persian at the University of Cambridge, will be published by Messrs. Williams and Norgate, Ltd., for the trustees of Herbert Spencer, in continuance of his "Deseriptive Sociology".

Applications are invited for the following appoint ments, on or before the dates mentioned :-A technical assistant to the Adviser in Agricultural Economies at Armstrong College, Newcastle-uponTyne-The Registrar (May 16). A full-time lecturer in chemistry at the Wigan and District Mining and Technical College-The Principal (May 19). A junior assistant bacteriologist and demonstrator at the University of Sheffield--The Registrar (May 20). A Sharpey physiological scholar at University College, London-The Secretary (May 27). A principal at St. Katherine's Training College for Women Teachers, Tottenham--The Rev. Canon G. L. Gosling, S.P.C.K. House, Northumberland Avenue, W.C.2 (May 31). A lecturer in mathematics at East London College, Mile End Road, E.1-The Registrar (May 31). A head of the Department of Electrical Engineering and a lecturer in the Department of Mechanical Engineering of the Central Technical College, Birmingham-The Principal (June 3). A lecturer in organic chemistry at the Manchester Municipal College of Technology-The Principal (June 14). A University lecturer and a University demonstrator in physies-The Secretary, Appointments Committee of the Faculty of Physics and Chemistry, Clare College, Cambridge. A mechanical engineer in the Egyptian Irrigation Service in the Sudan-Chief Inspecting Engineer, Egyptian Government, 41, Tothill Street, S.W.1. A full-time assistant in the Engineering Department of the Technical College, West Hartlepool--The Secretary, Education Offices, Park Road, West Hartlepool. A plant engineer for the locomotive, carriage and waggon shops of the South Indian Railway Co.Messrs. Robert White and Partners, 3, Victoria Street, London, S.W.1. 